\title{
Citizenship Education and Its Implications for Education
}

\author{
Ali Ghasempoor ${ }^{1}$, Peyman Yarmohammadzadeh ${ }^{2} \&$ Zahra Pishkarmofrad $^{3}$ \\ ${ }^{1}$ Department of Education, Payame Noor University, Tehran, Iran \\ ${ }^{2}$ School of Educational Sciences and Psychology, Azarbaiejan University of Tarbiat Moallem, Tabriz, Iran \\ ${ }^{3}$ Zahedan School of Nursing and Midwifery, Zahedan University of Medical Sciences, Iran \\ Correspondence: Ali Ghasempoor, Department of Education, Payame Noor University, PO Box 19395-3697, \\ Tehran, Iran. Tel: 98-937-547-9760. E-mail: alighasempur@gmail.com
}

Received: January 21, 2012

Accepted: April 25, $2012 \quad$ Published: June 1, 2012

doi:10.5539/jel.v1n1p109

URL: http://dx.doi.org/10.5539/jel.v1n1p109

\begin{abstract}
This paper addresses the purpose of citizenship education and its role in educational setting. Citizenship is the core concept that provides the learning focus for social studies at all grades. To identify the skills, knowledge, and values that students will need as active democratic citizens, social studies must take into account the society in which students live, and anticipate the challenges they will face in the future. Citizenship is a fluid concept that changes over time: its meaning is often contested, and it is subject to interpretation and continuing debate. Citizenship education is fundamental to living in a democratic society. The concept of citizenship takes on meaning in specific contexts and is determined by time and place. Diverse notions of citizenship have been used in the past and are being used in the present, for both good and ill. The purpose of this study is, surveying the nature of citizenship and its implication for education. This paper explores the ways in which citizenship education is used in an effort to create particular kinds of citizens as part of a larger effort in education systems.
\end{abstract}

Keywords: citizenship, education, education policy, implication

\section{Introduction}

"Citizenship" is the school subject area in which Local Lawyers in Schools best sits, in fact the session materials are mapped on to the Citizenship curriculum.: "Citizenship education" has been the subject of growing attention in policy, education and academic circles over the past 20 years (cf. Lockyer et al, 2004, Ortloff, 2005; Osler and Starkey, 2006; Stevick and Levinson, 2006; Torney-Purta et al, 1999).

Various reasons for this resurgence of interest have been cited, but a key concern amidst the debates has been the transformation of governance and the increasing strength of local, regional, and global institutions and citizenships. Citizenship education curricula have typically focused on national institutions, issues, and ties. However, the emergence, or re-emergence, of sub- and supra-national institutions has meant that citizenship education curricula are now supposed to embrace local, regional, and global citizenships as well as national citizenship (Stromquist, 2008).

This reality presents a fundamental challenge to traditionally held notions of citizenship education (Keating et al, 2011). Indeed these reforms require reconsideration of the very basis of citizenship education in nation-states. Citizenship education has been closely bound up with the legitimacy of the nation-state, and these alternative institutions and citizenships present a significant test not only to the contents of national curricula, but also to the traditional purpose and assumptions of citizenship education (cf. Heater 2003, 2004).

Citizenship education's program is ambitious. Citizenship is no longer merely a cross-curricular theme, but neither is it merely a curriculum subject. Citizenship education is a network that threads across the whole school. It can be taught as a discrete subject or included in other curriculum subjects, or both; it links with extracurricular activities; it expects each pupil to enjoy real democratic participation in their school through a School Council. The citizenship education program of study has three strands. Strand 1 includes a considerable body of knowledge to enable pupils to become politically literate citizens. Strand 2 seeks to develop pupils' skills of enquiry and communication, through discussion and debate. Strand 3 seeks to develop pupils' skills of participation and responsible action, enabling them to take part in active citizenship through involvement in community activities, such as volunteering (Watson, 2004). 


\section{Researching Citizenship Education}

Citizenship education involves a wide range of different elements of learning, including:

1) Knowledge and understanding: About topics such as: laws and rules, the democratic process, the media, human rights, diversity, money and the economy, sustainable development and world as a global community; and about concepts such as democracy, justice, equality, freedom, authority and the rule of law;

2) Skills and aptitudes: Critical thinking, analysing information, expressing opinions, taking part in discussions and debates, negotiating, conflict resolution and participating in community action;

3) Values and dispositions: Respect for justice, democracy and the rule of law, openness, tolerance, courage to defend a point of view and willingness to: listen to, work with and stand up for others.

Although the notion of citizenship has been traced back to Ancient Greece (see Heater 2004a), there is as yet no academic consensus on its components, conceptual parameters or implications. From a sociological perspective, citizenship has been broadly defined as 'a set of social practices which define the nature of social membership' (Turner 1993, p. 4).

In the past, it has often been assumed that the community in question was a nation-state, and indeed, that citizenship was seen as inextricably linked to the nation-state. As Turner observes (2006, p. 225), "the development of citizenship is also a project of nation-building in which the creation of the national citizen is the primary project of the nation-state". Education (and in particular, formal schooling) played a key role in this process. The consolidation of the modern nation-state was predicated on the creation of common bonds such as a shared language, history and symbols. Schools provided an ideal medium through which to introduce these "shared" features to future generations, as well as providing students with the information, literacy and skills required for political and economic participation in the nation-state (see Gellner, 1983; Hobsbawm, 1987; Heater, 2004b). As a result, national education systems became "a massive engine of integration" through which the state attempted to "to create the civic identity and national consciousness which would bind each to the state and reconcile each to the other" (Green, 1997, p. 134). In tracing the relationship between the invention of the nation-state and education, researchers have highlighted that national curricula have typically demonstrated a number of features, namely: a strong emphasis on patriotism, a celebration of the culture and history of the "nation", and a mythologizing of national heroes and events (keating, 2009).

The curriculum also tended to be ethnocentric, and reliant on establishing an "in"-group and an "Other" (Green 1997; Soysal, 2002). However, the rise of transnational sites of citizenship(s) has raised the question of whether the concept (and practice) of citizenship is inextricably bound to the nation-state, or alternative conceptualizations can (or indeed, must) be found (Wiener, 1998, Turner, 2006). These developments and debates have, in turn, raised questions about how we conceptualize the manifestation of European citizenship projects in education. Do European institutions provide a different model or form of citizenship than nation-states? If so, can we measure or analyze European citizenship education polices against the same criteria as nation-states? That is, do European policies utilize the same techniques as nation-states to promote citizenship through education, or do we need a new 'post'-national way of describing and characterizing the way in which European institutions seek to instill citizenship through education? (keating, 2009).

The new sites of citizenship created by globalization are often labeled as cosmopolitan or post-national models of citizenship, where post-nationalism is defined as "any form of citizenship not exclusively defined by the nation state" (Delanty, 2000, pp. 64-65). This is a rather broad, and unhelpful, categorization, but, over time, scholars have helped to define and refine the features of this concept. Soysal (1994), for example, has suggested that in the post-national state, citizenship rights are based on universal principles and international law (for instance, the UN Convention on Human Rights) which, even if non-binding in legal terms, encourage state compliance through their ability to establish norms, frame discourses, and define competence and goals (Soysal, 1994). As a result, rights are becoming universalistic, uniform (at least in legal terms), and abstract and defined at global level. At the same time, identities remain particularistic and territorially defined, but as identities no longer necessarily engender rights and privileges, citizenship rights and citizenship identity have been de-coupled and nationalist identity and post national citizenship can co-exist (Soysal, 1994).

These theories have, in turn, been taken up in citizenship education research, and in particular, within academic debates about education for global and cosmopolitan citizenship. Central to these discussions has been the questions: what should or could a truly post-national education look like? Moreover, what differentiates the national model of citizenship education from the post-national model? In the efforts to address these questions, various distinctions and features have been proffered (see, for example, Soysal, 1994, 2002; Rauner 1998; Heater, 
1999).

\section{The Transformations of Citizenship}

Ever since its first classical formulation, provided by Marshall (1964) in a series of lessons held in 1949, citizenship in modern western thought has been closely tied to the nation-state. The equation "a nation-state $1 / 4 \mathrm{a}$ land $1 / 4 \mathrm{a}$ people $1 / 4 \mathrm{a}$ citizenry" functions as a guide for the distribution of rights and duties that constitutes the basis of civil cohabitation in the democratic model. Although it is possible to highlight the historical relevance of local identities in defining the actual possibility of enjoying the rights conferred by citizenship (Fahrmeir and Jones, 2008), the progressive development of an ever-wider recognition of individual rights long seemed indistinguishable and inseparable from a growing reinforcement of the nation-state. In a perspective that removes every possible distinction between state - the political-institutional regulation of a specific territory - and nation - the sense of belonging to a defined and cohesive community - the consolidation of the state apparatus and a certain level of nationalism often seemed synonymous with the widening of subjective rights, individual freedom and participation in collective decisions. Starting from the mid-1970s, the strict marriage between state, nation and the recognition of rights began to be questioned. The intensification of the speed and reach of processes of globalization - in particular flows of people, ideas and goods (Appadurai, 1996), not to mention the planetary interconnections that seem more and more to unite people and phenomena over great distances in complex systems of dependency and mutual influence (Tomlinson, 1999) - transforms the idea of citizenship, highlighting the contradictory link that binds belonging to a political community to the protection of individual and collective rights (Colombo et al. 2011).

Citizenship thus becomes one of the principal terrains of conflict over sovereignty and identity, comprising demands for the recognition of collective differences and, more generally, spreading instances of the transformation of rules for managing public and political spaces (Castles and Davidson, 2000; Delanty, 2000). More specifically, migratory processes are particularly efficient for underlining the incongruities and implicit assumptions of "pense'e d'Etat" (Sayad, 1999). The latter establishes itself as a space for protection, participation and development of individual potentialities only insofar as it is able to exclude those considered 'foreign'. Simultaneously, it aspires to widen the area of its sovereignty as far as possible, yet is faced with the limitation that the more citizenship becomes inclusive and widespread, the less it has to offer. The presence of the migrant leads to the deconstruction of the apparent unity of citizenship, highlighting the fact that the recognition of rights (civil, political and social), and of identity and the willingness to participate in collective life, may constitute distinct elements that may also diverge or compete with each other. The children of migrants render this dissociation particularly obvious: far from being the simple extension of their parents' "native soil", and indeed from embracing without regret or resistance the models of their fellow "natives", these people highlight the distinction between national identity and citizenship (Hussain and Bagguley, 2005), elaborating multiple and diverse individual and collective identities that demand recognition and participation according to criteria dissociated from - or not entirely reducible to - a single ethnic or national identity (Colombo et al. 2009b). Taking the cultural symbols necessary for the elaboration and communication of their specific identity from the global cultural stream, both from their parents' native nations and from those in which they were born and grew up, they present requests for the recognition of citizenship that remain distinct from a full and total identification with a presumed community able to furnish models and meanings for every aspect of their experience (Soysal, 2000).

Belonging, participation and the recognition of rights reveal themselves to be aspects that are partially autonomous, never completely traceable to the idea of national identity (Colombo, 2010; Delanty, 2000). Being a society no longer necessarily coincides with being a nation because, in certain aspects, society exceeds the nation: one can and one may wish to participate without feeling that one belongs "exclusively", "completely" and "definitively"; one participates not because one identifies with the nation, but because one feels involved (because of personal interests, feeling "affected", because in this way individuals can claim the recognition of their own particularity). This paper aims to explore how children of immigrants enrolled in higher secondary schools in Milan (northern Italy) conceive and speak about citizenship. In particular, it illustrates how the formal, participatory and identity dimensions of citizenship come to be articulated in a complex and changeable way in relation to discourses and contexts. As a result, the connection between belonging and citizenship blurred. The sense of belonging becomes plural, yet without blunting the demand for full membership and equal participation, sheds a new light on the entire category of citizenship. Assuming this analytical perspective, the present article attempts to look more closely at the transformations of belonging, which today seems to be composed of different layers: admittance stresses the universalistic claim to be equal, to not be excluded on the basis of discrimination or prejudice; identification conserves a particularistic and essentialist meaning, it stresses the 
importance and the "unavoidableness" of difference; involvement regards lifestyles, everyday relations, it confers importance on the possibility to participate on behalf of a specific interest and play one's cards well, to have a stake in a community's life and future. Therefore, citizenship assumes different meanings when discourses shift from one layer to another (Colombo et al, 2011).

\section{Visible Citizenship}

One of the most obvious signs that citizenship has become established in schools is when children are entered as candidates for Graduate Certificate in Education (GCSE) Citizenship Studies. This has been commended by Ofsted who claim that participation "in GCSE citizenship short courses has been generally associated with greater focus, better teaching and higher standards and achievement" (Ofsted, 2005, p. 3). Indeed, the setting up of citizenship departments is singled out for praise where "some or all pupils are following accredited courses including short course GCSE" (Ofsted, 2005, p. 3).

Specialist teaching in timetabled periods tends to be advocated and Ofsted promote the approach to citizenship where it is taught as a "National Curriculum subject" that has a "strong and identifiable core program" and "involves homework" (Ofsted, 2005, p. 3). Finding time each week on the school timetable and adding "citizenship" to it is encouraged; Eltham Girls School in Greenwich has been singled out for praise as an institution "where citizenship is a strength' because it gives 'an hour a week for [citizenship] lessons' and has 'a team of specialist teachers" (Bell, 2005).

We are told that when such a "core program taught by a small group of specialists" is augmented by "participation and responsible action on activity days" this "works well" because the subject has "an identity to which pupils can relate" (Ofsted, 2005, p. 4). Evidently, "identity", or what has been termed here "visibility", is being valorized. Schools that were visited during 2004-2005 provided such events as a Human Rights Day (where speakers from outside the school worked with children) and a Criminal Justice Day (where children attended a court and participated in a mock trial). The student teachers following the Post-graduate Certificate in Education (PGCE) Citizenship course, led by the author, planned such a day, in conjunction with one school's citizenship coordinator, and provided a range of workshops for children. Partner schools also worked on themes such as inclusion and equal opportunities where teachers devised innovative workshops to broaden pupils' experience and understanding of these issues. While such days are generally enjoyable for children and raise the profile of the subject they are not always sufficiently related to what children learn across the curriculum or throughout the year as members of a school community (Pike, 2007).

\section{Invisible Citizenship}

There are numerous advantages to citizenship being integrated within other subjects so long as the necessary specialist knowledge is acquired. Yet Ofsted does not appear to encourage the 'cross-curricular route'; we are told "evidence suggests that, so far, pupils are confused by cross-curricular approaches" (Bell, 2005). Officially, the "audit-of-what-we-already-do" method appears to be considered unsuccessful although many schools prepared for the introduction of citizenship with an audit of links, typically compiling a matrix to show where citizenship-related issues could be found across the curriculum. Indeed, such an approach should not be eschewed for recent research reports such a method being successfully employed in a school that "had conducted a citizenship audit which provided a grid showing where citizenship opportunities occurred across the curriculum" (Davies et al., 2005, p. 79).

Yet we are led to believe that an inherent problem with teaching citizenship through other subjects is that children are "not aware that they have had a citizenship program" (Bell, 2005, italics added); in other words, it is insufficiently visible. Less visible aspects of citizenship such as school organization, assessment procedures, ethos and so on (from which children learn important lessons) are not receiving sufficient endorsement and encouragement, it would seem, because children might be unaware this is "citizenship". We are told that "citizenship is not about the way a school goes about its business, or its ethos" (Bell, 2005) even though, according to the Crick Report, there is "increasing recognition that the ethos, organization, structures and daily practices of schools, including whole school activities and assemblies, have a significant impact on the effectiveness of citizenship education" (QCA, 1998, p. 36). Many parents would certainly regard hidden aspects of a school's life such as its ethos to be rather important in learning what it is to be a good citizen. Indeed, the way a school "goes about its business" is considered by some to be central to aspects of citizenship education although it may not be visible on a school's timetable. The observation that citizenship is "not about ethos or school organization" may be valid within the context of the aim of citizenship to produce informed citizens (as children need to be taught in a coherent way about how local government or the criminal justice system works, for instance) but it makes much less sense if the other, broader, aims of citizenship education (concerning values, 
commitments and participation) are to be achieved. Teaching citizenship together with PSHE is, apparently, especially difficult and "the perceived close relationship between citizenship and PSHE is proving problematic" because "PSHE is about the private, individual dimension of pupils' development, whereas citizenship concerns the public dimension" (Bell, 2005). We are told that "conflict resolution in citizenship is not about the problems experienced in individual parent-teenager relationships" (Ofsted, 2005, p. 6) but when teaching and learning makes the transition from exploring personal conflict resolution to global conflict resolution (and the role of the United Nations for instance) this does qualify as citizenship. Issues 'take on a citizenship dimension when the questions addressed are to do with topical local and national issues, policy, and what can be done to bring about change' (Ofsted, 2005, p. 6). Marrying citizenship to PSHE to the extent that it loses its own identity may be problematic but divorcing citizenship entirely from PSHE is not likely to help young learners see the relevance of citizenship to their personal lives.

The significance of citizenship for learning to live seems to be insufficiently appreciated within official recommendations that see successful citizenship education being achieved by turning it into an examined school subject and improving its status. Citizenship education concerns school ethos which is important because it is about the way a school corporately lives its life. Ethos refers to "the pervasive atmosphere, ambience or climate within a school" (Halstead \& Taylor, 2000, p. 17) and is derived from the quality of relationships, feelings of community, dominant patterns of discourse and social interaction as well as classroom layout, assessment policies, visual culture and the extent to which children, parents and teachers work together. Such features of school life often teach children a great deal about citizenship and their own worth and should not be dismissed because they are less visible than timetabled "citizenship". One aspect of life in school that teaches children about power relations within society and their place in it is the assessment practices they experience; the control a school exerts over learners through such practices is significant for citizenship education but is not immediately visible to schools or even, it would seem, to researchers (Pike, 2007).

\section{Implications for Citizenship Education}

The challenge for citizenship education programs and curricula is how to develop discourses and practices that cultivate a renewed sense of citizenship for each and every student-a citizenship that is grounded on the demands of conviviality and hospitality.

The notions of conviviality and hospitality as critical tools of developing an alternative citizenship education suggest a reorientation of our attention towards the myriad pedagogical practices through which emotions and affects towards citizenship are worked up and maintained. Traditional citizenship education discourses privilege a juridical culture, and clearly lack an explicit investigation of the ways in which ideas such as conviviality and hospitality can be used for more critical forms of citizenship; that is, forms of citizenship that do not ignore the role of emotions and affects as important aspects of forming alternative affective economies. Consequently, a reconceptualization of citizenship education paradigms through the inclusion of conviviality and hospitality has two major advantages.

First, the discourses on conviviality and hospitality restore a sense of otherness because they constitute resources of developing new affective attachments that extend ethical responsibility, care and justice; these discourses focus their concerns on the ways that ethical responsibility, care and justice form both critical and cosmopolitan affective communities. Secondly, conviviality and hospitality bring into view a set of differential openings in the analysis of affective networks within particular socio-political fields and citizenship education. For example, an understanding that fear of Muslims after $9 / 11$ or of immigrants is an effect of the affective encounters within a community and may have ideological roots helps students (notably those who belong to the dominant group) to question how ideas such as conviviality and hospitability may create new affective attachments with marginalized others. The above arguments urge educators to consider how the cultivation of particular emotions for those who are "different" - through citizenship education curricula, textbooks and every day school practices - organizes the social and bodily space in the field of citizenship education by creating powerful affective borders. Consequently, the task of any citizenship education pedagogy that is critical of these affective borders among individuals and groups is to identify the practices, strategies and spaces where affective transformation might be possible. Conviviality and hospitality have the potential to instill such transformation, by restructuring the affective field of citizenship education pedagogies; these notions redefine citizenship by re-educating the emotions of citizenship.

I want to highlight two implications of the account developed here. The first implication is the importance of analyzing the emotional modes/discourses through which sentimental citizenship education is authorized by, implied and embodied, and recognizing that such discourses have consequences for the ways in which affective 
communities are constituted (within the classroom and beyond). Hence to take seriously the affective politics of citizenship education is to explore how such modes and discourses are part of the efforts to articulate a different relationship between the self and the other (Giroux 1997). That is, analysis of the affective politics of citizenship education involves the interrogation of the ways in which explicit mobilization of emotions produces exclusive definitions of citizenship. Educators and their students need to question, for example, whether the mobilization of emotions simply tolerates otherness - toleration as that which implies something to get over - or really welcomes a guest as Somebody through whom new powerful networks of solidarity emerge (Gordon 1999). The question, writes McCormack, "is not only 'how far can we care', but also becomes one of cultivating a commitment to those relations that may increase the intensity of attachment and connectivity" $(2003,503)$.

Consequently, a critical citizenship education that problematises the normative politics of emotion points to the need to identify how discourses and practices are embodied in the day-to-day routines of school life, and to explore the possibilities that are opened for interrupting policies and practices that exclude and dehumanize others. Such a form of citizenship education includes the development of a mode of critique that comprehends the affective economies of citizenship as well as their effects on students and teachers' lives. It is realized, therefore, that students and teachers bring different emotional histories with them to school, and that these histories are embedded in a wider context of sociopolitical forces, needs, and interests (Zembylas, 2009).

Hence these emotional histories need to be constantly interrogated rather than taking for granted the constraining conditions of defining affects in merely celebratory terms. The second implication is that inasmuch as a critical citizenship education acknowledges how schooling perpetuates hegemonic emotion discourses about borders, hosts, and strangers, educators and their students need to examine the individual and community spaces that may be constituted to disrupt these hegemonies.

Conviviality and hospitality offer some possibilities for transforming educators and students' dispositions; the literature on inclusive, anti-racist and critical pedagogies can provide numerous practical examples engendering the notions of conviviality and hospitality and debunking polarities such as host/stranger (see Zembylas, 2007).

However, it needs to be acknowledged that the disruption of normative politics of emotion around citizenship (particularly civic republican and liberal citizenships) is certainly not an easy task for educators. The dispositions of the hegemonic citizenship discourses are not easily suspended by a simple effort or will. Affective communities embedded in national sentimentality are not easily undone through an educational program in which ideas of conviviality and hospitality are somehow infused. The issue, as Bourdieu asserts, is not "a simple 'conversion of minds' ... produced by rational preaching and education" $(2000,180)$, because passions are rooted in emotional dispositions. What is most often required is a transformation of the very conditions, emotional and otherwise, of the production and re-production of the economies of emotions around hegemonic meanings and practices of citizenship. Undoubtedly, this is a much more difficult task (Zembylas, 2009).

\section{Conclusion}

Citizenship is more than a subject. If taught well and tailored to local needs, its skills and values will enhance democratic life for all of us, both rights and responsibilities, beginning in school and radiating out. Citizenship is the core concept that provides the learning focus for social studies at all grades. To identify the skills, knowledge, and values that students will need as active democratic citizens, social studies must take into account the society in which students live, and anticipate the challenges they will face in the future. Citizenship is a fluid concept that changes over time: its meaning is often contested, and it is subject to interpretation and continuing debate. Citizenship education is fundamental to living in a democratic society. The concept of citizenship takes on meaning in specific contexts and is determined by time and place. Diverse notions of citizenship have been used in the past and are being used in the present, for both good and ill. The challenge for citizenship education programs and curricula is how to develop discourses and practices that cultivate a renewed sense of citizenship for each and every student - a citizenship that is grounded on the demands of conviviality and hospitality.

In this paper we highlighted two implications of the account developed. The first implication was the importance of analyzing the emotional modes/discourses through which sentimental citizenship education is authorized by, implied and embodied, and recognizing that such discourses have consequences for the ways in which affective communities are constituted (within the classroom and beyond). The second implication was that inasmuch as a critical citizenship education acknowledges how schooling perpetuates hegemonic emotion discourses about borders, hosts, and strangers, educators and their students need to examine the individual and community spaces that may be constituted to disrupt these hegemonies. What is most often required is a transformation of the very conditions, emotional and otherwise, of the production and re-production of the economies of emotions around hegemonic meanings and practices of citizenship. Undoubtedly, this is a much more difficult task. 


\section{References}

Bell, D. (2005). Citizenship, paper presented at the Hansard Society Conference. Retrieved from http://www.ofsted.gov.uk/publications/index.cfm?fuseaction5pubs.summary\&id53821

Castles, S., \& Davidson, A. (2000). Citizenship and Migration: Globalization and the Politics of Belonging. London: Routledge.

Colombo, E. (2010). Changing citizenship: everyday representations of membership, belonging and identification among Italian senior secondary school students. Italian Journal of Sociology of Education, 4(1), 129-53.

Colombo, E., Leonini, L., \& Rebughini, P. (2009b). 'Different but not stranger: everyday collective identification among adolescent children of immigrants in Italy'. Journal of Ethnic and Migration Studies, 35(1), 37-59. http://dx.doi.org/10.1080/13691830802489101

Colombo, E., Domaneschi, L., \& Marchetti, C. (2011). Citizenship and multiple belonging. Representations of inclusion, identification and participation among children of immigrants in Italy. Journal of Modern Italian Studies, 16(3), 334-347. http://dx.doi.org/10.1080/1354571X.2011.565630

Davies, L., Harber, C., \& Yamashita, H. (2005). Global citizenship education: the needs of teachers and learners (report on DFID funded research project) (Birmingham, Centre for International Education and Research (CIER), School of Education, University of Birmingham). Retrieved from http://www.education.bham.ac.uk/research/cier/documents/Global_itizenship_Report

Delanty, G. (2000). Citizenship in a global age: society, culture and politics. Buckingham: Open University Press.

Fahrmeir, A., \& Jones, H. S. (2008). Space and belonging in modern Europe: citizenship(s) in localities, regions, and states. European Journal of History: Revue europeenne d'histoire, 15(3), 243-253.

Gellner, E. (1983). Nations and nationalism. Ithaca: Cornell University Press.

Green, A. (1997). Education, globalization and the nation state. Basingstoke and New York: Macmillan Press. http://dx.doi.org/10.1057/9780230371132

Giroux, H. (1997). Pedagogy and the politics of hope: Theory, culture and schooling. Boulder, CO: West view Press.

Gordon, P. (1999). Face to face: Therapy as ethics. London: Constable.

Halstead, J. M., \& Taylor, M., J. (2000). The development of values, attitudes and personal qualities: a review of recent research (Slough, National Foundation for Educational Research).

Heater, D. (1999). What is citizenship? Cambridge, Oxford and Malden: Polity Press.

Heater, D. (2003). A History of Education for Citizenship. London: Routledge Falmer.

Heater, D. (2004a). A history of education for citizenship. London: RoutledgeFalmer.

Heater, D. (2004b). Citizenship: The Civic Ideal in World History, Politics, and Education (3rd ed). Manchester, UK: Manchester University Press.

Hobsbawm, E. (1987). The age of empire. London: Abacus. Isin, E.F. and Turner, B., 2002. Citizenship studies: an introduction.

Hussain, Y., \& Bagguley, P. (2005). Citizenship, ethnicity and identity: British Pakistanis after 2001 "Riots". Sociology, 39(3), 407-25. http://dx.doi.org/10.1177/0038038505052493

Keating, A., Hinderliter, O., \& Philippou, S. (2009). Citizenship education curricula: the changes and challenges presented by global and European integration. Journal of Curriculum Studies, 41(2), 145-158. http://dx.doi.org/10.1080/00220270802485063

Keating, A. (2009). Educating Europe's citizens: moving from national to post-national models of educating for European citizenship. Citizenship Studies, 13(2), 135-151. http://dx.doi.org/10.1080/13621020902731140

Lockyer, A., Crick, B., \& Annette, J. (eds) (2004). Education for Democratic Citizenship: Issues of Theory and Practice. Aldershot, UK: Ashgate, 139-148.

McCormack, D. P. (2003). An event of geographical ethics in spaces of affect. Transactions of the Institute of British Geographers, 28, 488-507. http://dx.doi.org/10.1111/j.0020-2754.2003.00106.x 
Marshall, T. H. (1964). Class, Citizenship and Social Development. Essays by T. H. Marshall, New York: Anchor Books.

Office for Standards in Education (Ofsted) (2005). Citizenship in secondary schools: evidence from Ofsted inspections (2003/04), reference no.HMI 2335, February 2003 (London, Ofsted).

Ortloff, D. H. (2005). Becoming European: a framing analysis of three countries' civics education curricula. European Education, 37(4), 35-49. http://dx.doi.org/10.2753/EUE1056-4934370403

Osler, A., \& Starkey, H. (2006). Education for democratic citizenship: a review of research, policy and practice 1995-2005. Research Papers in Education, 21(4), 433-466. http://dx.doi.org/10.1080/02671520600942438

Pike, M. A. (2007). Values and visibility: the implementation and assessment of citizenship education in schools. Educational Review, 59(2), 215-229. http://dx.doi.org/10.1080/00131910701255020

Qualifications and Curriculum Authority (QCA) (1998). Education for citizenship and the teaching of democracy in schools (The Crick Report) (London, QCA).

Rauner, M. (1998). Citizenship in the curriculum: the globalization of civics education in Anglophone Africa, 1955-1995. In C.L. McNeely, (Ed.). Public rights, public rules: constituting citizens in the world policy and national policy. (pp. 107-124). New York and London: Garland.

Stevick, E. D., \& Levinson, B. A. U. (eds) (2006). Reimagining Civic Education: How Diverse Societies Form Democratic Citizens (Lanham, MD: Rowman \& Littlefield).

Stromquist, N. P. (2008). Theorizing global citizenship. Paper presented at the Comparative and International Education Society (Los Angeles: University Southern California, Rosier School of Education).

Soysal, Y. (1994). Limits of citizenship: migrants and post national membership in Europe. Chicago: Chicago University Press.

Soysal, Y. (2002). Full report of research activities and results of the One World project. Retrieved from http://www.esrcsocietytoday.ac

Tomlinson, J. (1999). Globalization and Culture. Chicago. IL: University of Chicago Press.

Torney-Purta, J., Schwille, J., \& Amadeo, J.-A. (Eds.). (1999). Civic Education Across Countries: Twenty-four Case Studies from the IEA Civic Education Project(Amsterdam: IEA). ERIC ED 431705.

Turner, B. S. (1993). Citizenship and social theory. London, Newbury Park and New Delhi: Sage.

Turner, B. S. (2006). Citizenship, nationalism and nation-building. In G. Delanty and K. Kumar, (Eds.). Sage handbook of nations and nationalism. (pp. 225-236). London, Thousand Oaks and New Delhi: Sage.

Watson, J. (2004). Educating for citizenship - the emerging relationship between religious education and citizenship education. British Journal of Religious Education, 26(3), 259-271. http://dx.doi.org/10.1080/0141620042000232319

Wiener, A. (1998). European citizenship practice: building institutions of a non-state. Oxford and Boulder, CO: West view Press.

Zembylas, M. (2009). Affect, citizenship, politics: implications for education. Pedagogy, Culture \& Society, 17(3), 369-383. http://dx.doi.org/10.1080/14681360903194376

Zembylas, M. (2007). Five pedagogies, a thousand possibilities: Struggling for hope and transformation in education. Rotterdam: Sense Publishers. 